\title{
Historical understanding and rethinking the foundations
}

\author{
Jurie le Roux \\ Department of Old Testament Studies \\ University of Pretoria
}

\begin{abstract}
This article contributes to the fundamental rethinking of New Testament scholarship being undertaken by New Testament scholars attached to the University of South Africa (UNISA), Pretoria, South Africa. The thrust of the article holds that the historical Jesus research is of the utmost importance and it puts the emphasis on the individuality of an event and the contribution of nineteenth century reflection on history. As point of departure and further elaboration it accentuates the notion that history writing must be a form of homecoming.
\end{abstract}

\section{INTRODUCTION}

In the broader South African context the University of South Africa (UNISA) has become the space for constant hermeneutical reflection and intense discussions on theory, exegesis and the understanding of the text. It thus seems right that these New Testament scholars should reflect on the theoretical foundations of our science in order to formulate the road ahead more clearly. This article is a contribution towards this thinking about renewal by stressing the importance of historical understanding.

In the article "history" does not have the meaning of facts about and exact depictions of the past but it is viewed as a form of homecoming. To find our way home, however, is not easy. Someone aptly said that the past is like another country and the road leading there is unknown (Schoeman 1998:1). The past remains a different world which no one seems able to penetrate. This, however, is not the end of the road. Home is never far but always close by. It lies within us, within our world and consists of our own daily experiences. Through these experiences we can understand people of other times. The key to our finding our way home thus does not lie in a method or fact finding missions but in ourselves. Since we are humans and the people of the past are of the same nature we can endeavour to understand them. These 
experiences will enable us to discover other worlds.

In what follows this perspective is elaborated further by formulating our hopes for the future in terms of the past. We are in Africa and share in western scholarship but also have a unique way of doing exegesis. More conscious reflection of our historical task and historical Jesus can be an important indication of the road ahead. First of all, however, some remarks on science and crossroads.

\section{SCIENCE AS A CROSSROAD EXPERIENCE}

It is not clear when the Africa ecclesiae began but by the mid third century. Cyprian of Carthage was already speaking on behalf of the whole African church. This church spanned a vast region and had certain characteristic features. It was independent from the church in Rome, developed an original form of ecclesiastical structure, an own liturgy and a specific kind of theology (Beatrice 2006:159-183). The early church in North Africa, however, was a blend between the local and the universal. On the one hand it was part of the huge Roman Empire but also a remote and even forgotten province. One could say that the North African church was situated on the intersection between two worlds; it was a classic illustration of the co-existence and tension of the particular (African) and the universal (the Roman Empire, the "universal church") (Coyle 2006:13-26).

And centuries later this is still the context of biblical scholarship in South Africa. It lingers on the intersection between the particular (Africa/ South Africa) and the universal (western scholarship). These two worlds or modes of thinking are inextricably linked and the tension between them must never be resolved. It is through our continual existence on the junction between Africa and the west that we understand our task as New Testament scholars more clearly.

\section{UNISA AT THE CROSSROADS}

An excellent example of such a crossroad event took place on March 31971 at Unisa. On that day a Unisa scholar, Willem Vorster, appropriated western scholarship in such a way that it shaped South African biblical scholarship for decades to come. He delivered a paper to members of the New Testament Society of South Africa in which he urged scholars to take cognizance of the results of modern linguistics (Le Roux 1994:1-32). His views were based on those of Johannes Louw, a South African professor in New Testament Greek who had already explored the possibilities of the newer linguistics. Vorster's paper all at once triggered a movement that would forever change the face of 
biblical studies in South Africa. In that paper he highlighted De Saussure's distinction between synchronical and diachronical linguistics (and the notion that synchrony always precedes diachrony); the focus on the final text (and the disregard for historical information); the method to be applied (structural analysis and the techniques of modern linguistics) and the terminology to be used (diachrony, synchrony) (Vorster 1971:139-148).

Something entirely new was introduced on that autumn day in seventy one at Unisa which set biblical scholarship into motion and which resulted in the establishment of a new approach (which subsequently received the status of 'normal science' in the Kuhnian sense) as well as a new community of scholars and a new of kind of scholarship. From that event came forth the terms 'synchrony' and 'diachrony' which became central to our biblical scholarship. They have become the brand names of our debates on exegesis, the driving force behind many a research project and the principal guide in the study of the Scriptures. It also shaped our scholarly endeavors into a scholarly battle: the battle of the signs (Loader 1978:1-40).

\section{THE BATTLE OF THE SIGNS}

\subsection{Meaning resides in the sign}

At the heart of our synchrony-diachrony debates lie a battle. A battle of the signs based on the questions: What does the sign (the word, expression, linguistic utterance) do? Does it disclose meaning or not? Does it reveal the author's intention or is that forever beyond our reach? Can a method (consisting of definite steps) be of any use in this regard? In the case of structural analysis the text was viewed as a system of signs wherein the individual sign occupied a very important position. Especially its relation to other signs in the same linguistic utterance and the "thing" it signifies (Derrida 1976:27-73).

This link between a sign (or word) and its reference (to things, events, people) was problematized by De Saussure to the extreme. He emphasized the autonomy of language and that the organization of linguistic material occurred in an autonomous way. Meaning of language was seen as generated within language itself. It is not derived from some outside reality which existed independently of language. Signs do not relate to things in the world but to other signs in the same stretch of language. And the meaning of a sign is, however, not determined by "common sense" but by searching for what lies below the text. Beneath the signs (or the words on the surface) lies 
concealed the real meaning. The visible signs (or words) in a linguistic utterance is "a system of 'coded' utterances which usually mean something other than what they appear to mean." Language is thus never transparent, clear or obvious but is always masked, hidden and oblique. And these hidden, concealed meanings must be made apparent, clear, lucid, and comprehensible by means of a method called structural analysis. Thus, meaning is after all "present" in the text albeit not apparent at first glance. It is nevertheless there; packed below the visible signs awaiting liberation by means of the right method (Spivak 1976:Iviii-Ixvii).

Structural analysis (in its South African form) thus works with a certain phenomenological reduction. In other words: there is a bracketing of the extralinguistic world. The single sign was sufficient. All that was required was the correct method and the correct execution of the different steps and soon the true sense of a text has been determined. It was, however, exactly at this point where synchronical or structural analysis began to crumble. More and more scholars experienced an elusion of the true meaning and a feeling of disillusionment with the method which excludes historical information (Kearney 1989:240-251). To work historically on the other hand was also difficult because the sign evades final meaning.

\subsection{The sign that escapes meaning}

When a text is read diachronically a different word game is being played. The text is then seen as void of any meaning and the signs are empty. We are then searching for signs (or facts) that are absent, for meaning that has vanished, for a fullness which is lost, for an event which is gone. The elusiveness of the past and the inaccessibility of a past event are typical features of diachronic study (Derrida 1976:102-107). A historical event denies us access because the moment it is being investigated, it is already too late; the event has already "left" so to speak and can no longer be studied in its completeness. When Israel's past is thus explored the true nature of the events can never be determined. We have lost something (the quintessence of those events) and no (historical) method whatsoever can retrieve it (cf Thiselton 1980:103-113).

The signs in the texts are only traces. Traces of something that is gone; traces left behind by the (actual) events. We therefore always know past events indirectly and from a distance. He or she who wants to know the past has to follow a detour (by means of traces). These signs (in the text) thus do not expose the past in its fullness. A trace is merely a trace "and never a presence to which the trace can be related." Hence traces also have an 
elusive character: it is present but also absent, it presents itself and also effaces itself (Goosen 1998:54-79).

To work synchronically is a very optimistic undertaking. Meaning lurks just below the surface and awaits the moment of retrieval through the right method. When toiling diachronically a feeling of loss is rather experienced. It is like being plunged into mourning because the eye can never penetrate the early church or the historical Jesus. Or: "Deep down, deep down inside, the eye would be destined not to see but to weep" (Caputo 1997:100-105). And the reason for this is because signs in the text are only traces of what once was or happened; traces which are present but also absent, illuminating but also obscuring.

\section{TRACES AND THE HISTORICAL JESUS}

When we rethink the foundations of our biblical scholarship the study of the historical Jesus must take a prime position. By means of a critical study scholarship can be enriched, theology can become mature and preaching be deepened. Put differently: we are badly in need of critical historical thinking about Jesus. In South Africa there is a lot of plain talk (in the Heideggerian sense) about Jesus. People have made Jesus an object, an objective entity "present-at-hand" ("vorhanden") which they idly use for their own purpose (Heidegger 1998:96-103, 219-222; Grondin 2001c:1-43). They usurped Jesus and he became theirs to manipulate, employ and exploit. They decided how he must be understood and how his earthly work should be viewed. Put differently: Jesus has become an instrument in the hands of "Das Man" ("They") who defined Him for us, who tell us what to think about Him and how to believe (Heidegger 1998:169-174). And by doing this they lulled many into a passive attitude where critical reflection on the historical Jesus has become a sign of unbelief. Consequently, "Das Man" has set the boundaries for belief and became very powerful in the life of ordinary people and their perceptions of God and Jesus (Kearney 1989:36-38; Grondin 2001a:1-10; 2001b:152159). Critical thinking is therefore an indispensable way of putting Jesus in a historical perspective and to deliver him from the hands of "Das Man".

This, however, is a complicated task. To work with traces is not easy and to attune our ears to the distant voices of the early church asks much. To deepen the problem we lack the intellectual framework which Albert Schweitzer has formulated. In his great work on the history of the historical Jesus research, Schweitzer stated that this scholarship could only have taken place in German theology (Schweitzer 1936:1). Only in the German temperament do we find the combination of "the living complex of conditions 


\section{Historical understanding and rethinking the foundations}

and factors - without which no deep theology is possible." And according to Schweitzer especially four factors contributed to this kind of scholarship: the high level of philosophic thought, critical acumen, sharp historical insight and a religious feeling. A combination of these factors "produced" a kind of critical scholarship that shaped New Testament studies and the investigation of the historical Jesus up to this day. Within this intellectual context a specific way of reading the New Testament was nurtured and a new language (terminology, concepts, hypotheses, etc) was formulated which shaped our understanding of the historical Jesus.

The scholarly community in South Africa never internalized this type of Schweitzerian "intellectual frame". What exactly did we miss? This question can be answered differently but a few examples will suffice. Primo, the impulses of the Reformation. These impulses gave rise to the rejection of tradition, the enormous emphasis on the Bible (in Greek and Hebrew) and the beginnings of historical criticism (Kraus 1969:6-43). Secundo, Gabler's clear distinction between a scholarly understanding of the Biblical scholarship and dogmatics.(cf Gabler 1992:489-502; Saebo 1987:1-16; Merk 1984:1-3). According to Gabler biblical theology was a historical enterprise and not supposed to be merged with or subsumed under dogmatic considerations. Tertio, the impact of the Aufklärung. And if it is true that the "historischkritische Wissenschaff" originated during the Aufklärung we never felt the urge to appropriate this approach and its results. In other words, we never experienced the pressure to come to grips with the historical critical method and its important results in our exegetical endeavours (Kraus 1969:80-113; Le Roux 1993:26-27; 2001:444-457)). Quarto, the negligence of a critical attitude. The new view of history which developed during the nineteenth century in Europe (Germany) never actually took root here. This view turned everything upside down and completely shattered existing images of the past. The historical approach became "ein Sauerteig, der alles verwandelt und der schlieszlich die ganze bisherige Form theologischer Methoden zersprengt" (Troeltsch 1913:730, 1922:729-753). With regards to the New Testament this implies that the traditional picture of Jesus and the early church's past was destroyed once and for all.

Despite some "ingredients" we might have missed, biblical scholarship in South Africa has accomplished much. It remains a proud achievement and at this juncture of our intellectual history we should perhaps focus more on the refinement of our historical thinking and on such topics as the historical Jesus. It is, however, difficult because all we have to follow up are traces. Put differently: each trace emphasizes that we have lost the singularity of the event. Each event has a certain distinctiveness which is characteristic of only 
that event. Each event has its own individuality which always lies beyond the grasp of reason. Each event has a uniqueness which will forever remain out of one's reach (Derrida 1995:372-395). All the traces of the historical Jesus accentuate the loss of the fullness of the event, the wholeness of the first century Jesus event.

\section{THE INDIVIDUALITY OF PEOPLE AND EVENT}

All thinking about the historical Jesus must start in the nineteenth century (cf Grondin 1999:11, 15). This means that our historical reflection must always be linked to the profound thinking about history and the historical Jesus of the past centuries. We must be immersed in and shaped by the endless discussions and astounding insights of that century; we must think differently from the nineteenth century but continue the critical historical research and reflection which begun two centuries ago (cf Le Roux 1997:401-423). There is yet another reason for being committed to nineteenth century thought: the emphasis on the individual and individuality. This was something new in western hermeneutics. Each author now had to be understood as an unique individual and this specific individuality of the author can only be grasped by going back to the origin of his/her thought. And to accomplish this we had to place ourselves into the whole world of the author; to understand the "innermost feelings" of the author; to re-create the original creative event; to re-produce the original act of production; to re-live the moments of re-creation when a piece of literature was "born" (Gadamer 1990:200-259). Although grammar, language, structures were of the utmost importance they must never be the final aim of exegesis. Everything boils down to the author's life history; to our ability to transform ourselves into the other and grasp instantly the individuality of an author or an era (Rothacker 1923:437).

This individuality has consequences for our understanding of the past: "Historisme is dan de opvatting dat eerst een historische benadering ons in staat stelt het wezen, de identiteit, of, zoals de historisten zelf graag zeiden, de 'indiviualiteit' van de objecten in de socio-historische werkelijkheid op het spoor te komen" (Ankersmit 1990:133). A historian's task consisted in the discovery of the individuality of each event or personality. Each history had to focus on the unique and describe that which cannot be repeated. This means that the value and the meaning of each epoch reside in itself. Other periods can neither explain its nature nor illuminate its significance. It is only by means of intuition that the historian becomes aware of this individuality. Never can the particular be deduced from general historical laws (Von Ranke 1890:325). 
In the quest for individuality no historian can put him-/herself above the daily flow of historical events in order to obtain an omniscient perspective. No one has the ability to look back from a given point in history in order to determine each event's full meaning and significance. Knowledge of the past will always remain unfinished, incomplete, and partial and historians will never be able to explain things like natural scientists. They only understand events and people but cannot explain them. According to Droysen, it is, however, a specific form of understanding: "forschenden Verstehen" (Droysen 1977:133). Never objective explanation but always understanding; understanding that is gained through continuous research. Never is the point reached where the final meaning of an event is determined (Warnke 1987:13-26) and historians can do no more than to be engaged in endless investigation of the sources: "Die Begriff des Forschens ... soll die Unendlichkeit der Aufgabe markieren ... Nur in 'rastloser' Durchforschung der Überlieferung, in der Aufschließung immer neuer Quellen und in immer neuer Ausdeutung derselben nähert sich die Forschung schrittweise der 'Idee'” (Gadamer 1990:219). Differently put: "The legitimacy of the historian's work therefore lies simply in the attempt to understand" (Warnke 1987:21).

For the study of the historical Jesus and the early church the search for individuality is of utmost importance. To overcome the problem of a historical minimum we must appropriate the idea that all history runs through us. We approach the past through ourselves. By means of our prejudices and our horizon of meaning we select facts and give meaning to events. And by means of spiritual empathy we are able to enter into the past, to give life and blood to the people of the first century and to make the past present (cf Eichrodt 1929:983-991). Another way of saying it is to use the word "reenactment": Knowledge of the past is gained when the past is re-enacted in the mind of the historian. All history is therefore "the re-enactment of past thought in the historian's own mind" (Collingwood 1994:215). And if the written account of the historical Jesus does not become a reconstruction of exact events but a reliving of the event we can perhaps understand something of the Jesus individuality of the past. And this is never accomplished by facts or the execution of the right method but by constant study of the New Testament and related sources.

\section{CERTAIN REQUIREMENTS TO BE MET}

According to Schweitzer it is only those who from their mother's womb have an instinctive feeling for the historical that are well equipped to write a history of Jesus (Schweitzer 1936:35). These people are able to work through all the 
minutiae of the text to find the pathway that leads to historical reality. Like a stream that finds its way through rocks and many other obstacles to the sea so the true historian also reaches the life contexts of the first century and Jesus. There is no substitute for historical intuition. Erudition can be useful but it is no substitute for solid historical work (Schweitzer 1936:1-12). Erudition can at times even be a burden because the erudite often suppresses historical information. This kind of erudition can especially be found amongst theologians.

It was this sharp historical feeling which enabled Hermann Reimarus to "see" the historical Jesus as clearly as never before (Schweitzer 1936:13-26). Johann Gottfried Herder is praised for his "intuitive historical grasp" aided by his ability to understand poetry (cf Barth 1975:260-264; Rogerson 1992:16; Berlin 2000:165; Ankersmit 2007:146). This intuitive historical feeling and insight helped him to understand the difference between the Synoptic Gospels and John. The latter was a reaction against the narrow-minded view of the Synoptic Gospels which saw Jesus basically as the Messiah of the Jews. According to Herder John changed that into Jesus as the Saviour of the whole world. Herder could "see" this because of his intuitive insights and his feeling for the historical information in the text (Schweitzer 1936:34-37). Friedrich Schleiermacher on the other hand is criticized for not having a historical mind. He wrote on the historical Jesus but he was unable to think historically. He was more interested in what Jesus can do for his system of theology than in the historical Jesus. His work is therefore not historical but theological (Schweitzer 1936:62-67). His unhistorical stance enabled dogmaticians to leap over the historical problems into a kind of a virtual world where theology remains outside the reach of critical theology (cf Barth 1975:360-400; Gadamer 1990:188-201; Thiselton 1992:204-236; Grondin 2000:86-96).

It was, however, in Ernest Renan that historical feeling, aesthetic power, artistic feeling, love for nature, literary competence and lust for life were united in a sublime way. These qualities enabled him to depict a Jesus who was really human By means of these qualities he succeeded in depicting Jesus as a real human figure who lived under the blue skies of Galilee. He impressed the "good Galileans" because never before had they heard such wonderful words. His speech charmed them and his person captivated them. These simple folk therefore admired $\mathrm{Him}$ and encouraged Him to continue what He has begun (Renan 1991:20-25).

By means of this intuitive feeling Renan was enabled to unlock the Gospels and to understand the life of Jesus. Renan was a skeptic, a historian and embodied the French intellectual mentality. Through his aesthetic power and feeling he revived the past. By means of artistic imagination he created a 
Jesus who was a true human figure and who came alive under the blue skies of Galilee. A contemporary German critique referred to Renan as the Frenchman who took the mummified figure of Jesus which was exhumed by German critical scholarship and endowed Him with such a life and an energy that He became a living human figure (Renan 1991:125-136).

Woven into his presentation of Jesus is the nature of Galilee. The climate, the geography, the vegetation, all contributed to Renan's historical understanding of the life and times of Jesus. Renan's aesthetic feeling made him sensitive for nature's contribution to the shaping of the life of Jesus; his imaginative powers linked the historical events of Jesus to geography; his creative historical mind placed Jesus so to speak in physical contexts where he could be understood better. This sensitivity for the soil which Jesus once touched is a striking characteristic of Renan's historical mind. In a Derridian way he had to grapple with vague traces of what once was Galilee but he used all information about the Galilean landscape to "build" his view of Jesus. Movingly he says:

We might say that in topography, as well as in history, a profound design has wished to conceal the traces of the great founder. It is doubtful whether we shall ever be able, upon this extensively devastated soil, to ascertain the places where mankind would gladly come to kiss the imprint of his feet ... The lake, the horizon, the shrubs, the flowers, are all that remain of the little canton, three or four leagues in extent, where Jesus founded his Divine work. The trees have totally disappeared ... The lake has become deserted. A single boat in the most miserable condition now ploughs the waves once so rich in life and joy. But the waters are always clear and transparent. The shore, composed of rocks and pebbles, is that of a little sea, not that of a pond, like the shores of Lake Huleh. It is clean, neat, free from mud, and always beaten in the same place by the light movement of the waves ... He (Jesus) returned always to his well- beloved shore of Gennesareth. There was the center of his thoughts; there he found faith and love.

(Renan 1991:125)

A striking feature of Jesus' earlier ministry was his abundance of happiness (Renan 1991:158-167). In the course of time there gathered around Him fishermen and common people. They were not intellectually skilled and did not know much but they abound in happiness. They led a simple life but were extremely happy. And it was Galilee's wonderful climate which "made the life of these honest fishermen a perpetual delight." At night they slept under the 
skies on the shore and out of this perpetual contact with nature grew a love and joy. Jesus lived with his disciples almost always in the open air:

\begin{abstract}
Sometimes he got into a boat, and instructed his hearers, who were crowded upon the shore. Sometimes he sat upon the mountains which bordered the lake, where the air is so pure and the horizon so luminous. The faithful band led thus a joyous and wandering life, gathering the inspirations of the Master in their first bloom. An innocent doubt was sometimes raised, a question slightly skeptical; but Jesus, with a smile or a look, silenced the objection. At each step - in the passing cloud, the germinating seed, the ripening corn - they saw the sign of the Kingdom drawing nigh, they believed themselves on the eve of seeing God, of being masters of the world; tears were turned into joy; it was the advent upon earth of universal consolation.
\end{abstract}

(Renan 1991:158)

According to Schweitzer some qualities are expected from the historical Jesus scholar. Qualities that would enable him/her to understand something of Jesus and the first century. These were of course shaped by the rise of the historical consciousness and the profound nineteen century reflection on history which we must constantly appropriate (Ankersmit 2007:11-20).

\title{
8. SOME IMPORTANT CONTRIBUTIONS
}

Three South African New Testament scholars have already made important contributions to the historical study of Jesus and the first century. Two of them, Pieter Botha and Pieter Craffert, are from UNISA and Andries van Aarde from the University of Pretoria.

Pieter Botha's point of departure is our common humanity. What links us to the past is a shared humanity and therefore he depicted the "human side" of the early church. Not the theology or message, but the people: "the humans in, behind, around the texts." To accomplish this he approached the text in an interdisciplinary way: "Archaeology and cultural anthropology are combined in order to activate the historical imagination" (Botha 2000:ii). Imagination has thus become a tool to "feel" one's way into the past and to understand the ordinary folk who followed Jesus. Botha's picture of the first century followers of Jesus is therefore very human. These people lived under harsh conditions; thirty percent of the crowd was between twenty and twenty nine years of age; especially disturbing was the fact that about all older people suffered from tooth decay and that about five percent of all deaths were due to 
tooth decay. They were bound to strict rules regulating daily life: a man rather walked with his peer group than with his wife as the latter could have been interpreted as bad manners (cf Botha 2000:1-100). Botha's depiction of the life world of the ordinary first century believer is a very humane attempt to understand the world of Jesus and his followers in its individuality. He illuminated the particularity of the first century by means of a historical imagination stimulated by archaeological and other extra-biblical information. And by doing this he illustrated that Jesus and the early Christians were not phantom-like figures who only conveyed eternal messages but human beings to which all people of all ages can relate.

Pieter Craffert's contribution lies amongst other things in his social models and the objects he investigated. In order to obtain a clearer view on first century belief he focused on institutions like the temple and customs like burial practices To accomplish his goal Craffert employed social models or "multiple lenses". They were indispensable tools for investigating, analysing and interpreting ancient societies (Craffert 1999b:iv). A cultural systems model enabled him to understand the way ancient people organised their social environment by means of certain institutions. In the Graeco-Roman world temples were not erected for private use but as the earthly dwelling places of the gods. According to ancient belief the gods controlled not only the individual but also the affairs of the city. Each city had its own god(dess) and worship took the form of ritual and sacrifice. Craffert explains how this religious institution acquired a special place in the lives of people and the community; he illustrates how these temples fulfilled a particular function as sacred places and as "vehicles" through which divine power was mediated. Craffert also depicted the Herodian temple in Jerusalem and formulated its meaning: "It is no exaggeration to say that the Temple and its symbolic maps of time, place, things and persons became the concrete structural expression of the core value of God's holiness and wholeness" (Craffert 1999b:66). Craffert investigated burial tombs and rituals in order to understand how first century people understood themselves:

The way people deal with their dead is often a window on the way they see themselves in relation to others, to the gods and to their place in the universe. Tombs and their content provide information not only about death and burial customs but also about the beliefs of living human beings... The material remains, unearthed by archaeology, together with the literary evidence, are to be used in constructing the cultural responses to death in the biblical world. 
Craffert thus showed us something new when he stressed the importance of institions and customs as windows on the first century world.

The first monograph in South Africa on the historical Jesus was written by Andries van Aarde (Van Aarde 1994:180-189). This is in many ways a moving book (Le Roux 2001:1-15). He was a professor at a faculty where ministers of religion are trained and he wanted to emphasize the value of historical Jesus research for the church (Van Aarde 2001:20). God's salvation became manifest in history; God revealed Godself in the man, Jesus; through Jesus the man God entered into our world and became real in a very human way. Thus, belief demands knowledge of the historical Jesus. Without this knowledge salvation becomes virtual. Jesus then becomes a phantom and everything said about him is but a passing thought that has no point of contact with our human existence (Van Aarde 2001:18). Van Aarde summarises: "If (historical) inquiry is denied at the doorstep, doubt will come through the window" (Van Aarde 2001:23). And if the historical Jesus is taken seriously, historical critical scholarship should also be taken seriously. The implications are amongst others: appropriating the history of research, dealing critically with texts and making a historical synthesis (history is not merely the identification, collection and description of facts, but a creative recreation and re-telling of the past). Van Aarde is continually conscious of the contents of the historical Jesus research from the nineteenth century until the present. He regarded a critical treatment of the texts as indispensable. He wished to hear the echo of Jesus' past in every fragment of the text. Van Aarde's depiction of the fatherless Jesus is, however, very touching because he related his own situation to that of Jesus:

My book is about the historical Jesus who filled the emptiness, caused by his fatherlessness, with his trust in God as his Father ... I did, however, become existentially impelled by Jesus' fatherlessness because it addressed my own situation ... I have come to learn through my own experience who Jesus was and still is, child of God. Yes it is an "ineffable mystery".

(Van Aarde 2001:6)

\section{CONCLUSION}

To approach the text historically is a rewarding undertaking. In the preamble of the article we referred to it as a form of homecoming, a realization that the road leading to the past runs through us. And sometimes it is an extraordinary experience. That is when we touch the past, so to speak, and we unexpectedly experience something of it. It happens when the Vernunft (in 
Kantian terms) fails to provide the categories to understand something and awe and admiration then overwhelms us (Kant 1990:1-100). To unexpectedly have a brief encounter with the past and understand something which lies beyond our linguistic grasp, can be a breathtaking moment (Kant 1968:90-96). And this kind of homecoming is always a joyful experience.

This has consequences for our understanding of the early church and the historical Jesus and UNISA's (and other) New Testament scholars can help us to understand these consequences more profoundly.

\section{Works consulted}

Ankersmit, F 1990. De navel van de geschiedenis. Groningen: Historische Uitgeverij. Ankersmit, F 1993. De historische ervaring. Groningen: Historische Uitgeverij. Ankersmit, F 2007. De sublieme historische ervaring. Groningen: Historische Uitgeverij.

Barth, K 1975. Die Protestantische Theologie im 19: Jahrhundert. Hamburg: Siebenstern Taschenbuch Verlag.

Beatrice, P B 2006. The treasures of the Egyptians. Studia Patristica XXXIX, 159-183. Berlin, I 2000. Three critics of the Enlightenment. London: Pimlico.

Berlin, I 2000. Three critics of the Enlightenment. London: Pimlico.

Botha, P J J 2000. Everyday life in the world of Jesus. Pretoria: Biblia Publishers.

Caputo, J 1997. The prayers and tears of Jacques Derrida. Indianapolis, IN: Indiana University Press.

Collingwood, R G 1994. The Idea of history. Oxford: University Press.

Coyle, J K 2006. Particularities of Christianity in Roman Africa. Studia Patristica XXXIX, 13-26.

Craffert, P C 1999a. Ilness and healing in the Biblical world: Perspectives on health care. Pretoria: Biblia Publishers.

Craffert, P C 1999b. Mediating divine powers: Perspectives on religion in the biblical world. Pretoria: Biblia Publishers.

Craffert, P C 1999c. Meeting the living among the dead: Burials, tombs and the afterlife. Pretoria: Biblia Publishers.

Derrida, J 1976. Grammatology. Baltimore, MD: John Hopkins.

Derrida, J 1976. Of Grammatology. Baltimore, MD: John Hopkins.

Derrida, J 1995. Points .... Stanford, CA: Stanford University Press.

Derrida, J 1997. Limited Inc. Evanston, Illinois, IL: Northwestern University Press.

Droysen, J G 1977. Historik, Band 1: Rekonstruktion der ersten vollstandigen Fassung der Vorlesungen (1857) Grundriss der Historik in der ersten handschriftlichen (1857/1858) und in der letzten gedruckten Fassung (1882). Stuttgart: Frommann-Holzboog.

Eichrodt, W 1929. Hat die Alttestamentliche Theologie noch selbständige Bedeutung innerhalb der Alttestamentliche Wissenschaft?, ZAW 47, 983-91.

Gabler, J P 1992. An oration on the proper distinction between Biblical and Dogmatic, in Ollenburger, B C, Martens, E A \& Hasel, G (eds), The flowering of Old Testament Theology, 489-502. Winona Lake, IN: Eisenbrauns. 
Gadamer, H G 1990. Wahrheit und Methode. Tübingen: JCB Mohr.

Gadamer, H-G 1993. Hermeneutik II. Tübingen: JCB Mohr.

Gayatri C \& Spivak, G C 1976. Translator's preface, in Derrida, J, On grammatology, Iviii-Ixvii. Baltimore, MD: John Hopkins.

Goosen, D 1998. Verlies, rou en affirmasie: Dekonstruksie en die gebeure. Fragmente 1, 54-79.

Grondin, J 1994. Der Sinn für Hermeneutik. Darmstadt 1994

Grondin, J 1999. Hans-Georg Gadamer. Tübingen: J C B Mohr.

Grondin, J 2000. Einführung zu Gadamer. Tübingen: J C B Mohr.

Grondin, J 2001a. Der Sinn für Hermeneutik. Darmstadt: Wissenschaftliche Buchgesellschaft

Grondin, J 2001b. Einführung in die Philosophische Hermeneutik. Darmstadt: Wissenschaftliche Buchgesellschaft.

Grondin, J 2001c. Von Heidegger zu Gadamer. Darmstadt: Wissenschaftliche Buchgesellschaft.

Gunkel, $\mathrm{H}$ 1903. The religio-historical interpretation of the New Testament, The Monist 13, 398-455.

Gunkel, H 1926/1927. The "Historical Movement" in the study of religion. ExpTimes 38, 532-536.

Heidegger, M 1998. Zijn en tijd. Nijmegen: SUN.

Huizinga, J 1950. De taak der cultuurgeschiedenis, in Verzamelde werken, VII. Haarlem: H D Tjeenk Willink.

Kant, I 1968. Kritik der Urteilskraft. Hamburg: Felix Meiner Verlag.

Kant, I 1990. Kritik der reinen Vernunft. Berlin: De Gruyter

Kearney, R 1989. Modern movements in European philosophy. Manchester: University Press.

Kraus, H-J 1969. Geschichte der Historisch-Kritischen Erforschung des Alten Testaments. Neukirchen: Neukirchener Verlag.

Le Roux, J H 1994. A brief description of an intellectual journey: On Willem Vorster's quest for understanding. Neotestamentica 28(3), 1-32.

Le Roux, J H 1997. Our historical heritage. OTE 10(3), 401-423.

Le Roux, J H 2001. No theory, no science. OTE 14(3), 444-457.

Le Roux, J H 2002. Andries van Aarde se vaderlose Jesus. HTS, 77-99.

Loader, J A 1978. Gedagtes oor gekontroleerde eksegese, HTS 34, 1-40.

Merk, O 1984. Gabler, Johann Philipp (1753-1826), TRE XXII, 1-3.

Renan, E 1991. The life of Jesus. New York: Prometheus Books.

Rogerson, J 1992. W ML de Wette: Founder of modern biblical criticism: An intellectual biography. Sheffield: Academic Press.

Saebo, M 1987. Johann Philipp Gablers Bedeutung für die biblische Theologie, ZAW 99, $1-16$

Schoeman, K 1998. Verliesfontein. Kaapstad: Human \& Rousseau.

Schweitzer, A 1936. The quest of the historical Jesus. London: A \& C Black.

Thiselton, A 1992. New horizons in hermeneutics. Grand Rapids, MI: Zondervan.

Thiselton, A C 1980. The two horizons. Exeter: Pater Noster.

Troeltsch, E 1913. Historiography, in Hastings J (ed), Religion and ethics, 716-723. Edinburgh: T \& T Clark. 
Troeltsch, E 1922. Ueber historisch und dogmatisch Methode in der Theologie. Gesammelte Schriften II, 729-753. Tübingen: J C B Mohr.

Van Aarde, A G 1994. God-with-us: The dominant perspective in Matthew's story. Pretoria: Gutenberg.

Van Aarde, A 2001. Fatherless in Galilee: Jesus child of God. Harrisburg, PA: Trinity Press International.

Vorster, W S 1971. Moderne linguïstiek en Bybelnavorsing, ThEv 4, 139-148. 